\title{
Robert Klimek
}

Towarzystwo Naukowe im. Wojciecha Kętrzyńskiego w Olsztynie; robertusklimek@wp.pl

\section{Pierwsze kościoły na Warmii i ich wpływ na rozwój dróg lokalnych}

\section{The first churches in Warmia and their influence on the development of local roads}

\section{Die ersten Kirchen in Ermland und ihr Einfluss auf die Entwicklung der örtlichen Straßen}

\author{
Słowa kluczowe: Warmia, kościoły parafialne, szlaki komunikacyjne, drogi kościelne, \\ Prusowie \\ Keywords: $\quad$ Warmia, parish church, communication routes, church roads, Prussians \\ Schlïsselwörter: $\quad$ Ermland, Pfarrkirchen, Kommunikationswege, Kirchenstraßen, Preußen
}

\begin{abstract}
STRESZCZENIE
W pierwszej części publikacji podjęto się analizy lokalizacji pierwszych kościołów odbudowanych przez Prusów w 1249 r. na obszarze Warmii w następujących miejscowościach: Jedun, Surimes, Bandadis, Slinia, Wuntenowe, Brusebergue. Następnie zwrócono uwagę na rozwój sieci parafialnej na obszarze dominium warmińskiego. Pierwszy kościół został wybudowany w Braniewie w 1280 r., następnie we Fromborku w 1288 r. powstał kościół katedralny. Rozwój sieci parafialnej w średniowiecznej Warmii prowadził także do powstania nowych dróg, zwanych zazwyczaj „drogami kościelnymi”. Szlaki komunikacyjne były powiązane z powstawaniem nowych ośrodków, w których koncentrowało się życie gospodarcze czy religijne. Drogi do kościoła najczęściej stanowiły utarte już szlaki. Jednak należy zwrócić uwagę na fakt, że zakładanie nowych parafii i lokacje nowych wsi łączyło się z powstawaniem sieci komunikacyjnej, której lokalnym ośrodkiem stawał się kościół parafialny.
\end{abstract}




\begin{abstract}
In the first part of the publication, an analysis was undertaken of the location of the first churches rebuilt by the Prussians in 1249 in the area of Warmia in the following towns: Jedun, Surimes, Bandadis, Slinia, Wuntenowe, Brusebergue. Then, attention was paid to the development of the parish network in the area of the Warmia. The first church was built in Braniewo in 1280, then a cathedral church was built in Frombork in 1288. The development of the parish network in medieval Warmia also led to the creation of new roads, usually called „church roads". Communication routes were associated with the emergence of new centers where economic or religious life was concentrated. The roads to the church were usually already well-worn routes. However, it should be noted that the establishment of new parishes and the location of new villages was associated with the creation of a communication network, the local center of which was the parish church.
\end{abstract}

\title{
ZUSAMMENFASSUNG
}

Der erste Teil der Publikation analysiert die Lage der ersten Kirchen, die 1249 von den Preußen in Ermland in den folgenden Städten wieder aufgebaut wurden: Jedun, Surimes, Bandadis, Slinia, Wuntenowe, Brusebergu. Anschließend wurde die Aufmerksamkeit auf die Entwicklung des Pfarrnetzes im Gebiet von Ermland gerichtet. Die erste Kirche wurde 1280 in Braunsberg (Braniewo) gebaut, und 1288 wurde in Frauenburg eine Kathedralkirche errichtet. Die Entwicklung des Pfarrnetzes im mittelalterlichen Ermland führte auch zur Entstehung neuer Straßen, die gewöhnlich als „Kirchenstraßen“ bezeichnet werden. Die Verkehrswege waren mit dem Entstehen neuer Zentren verbunden, in denen sich das wirtschaftliche oder religiöse Leben konzentrierte. Bei den Wegen zur Kirche handelte es sich zumeist um bereits bestehende Routen. Es sei jedoch darauf hingewiesen, dass die Gründung neuer Pfarreien und die Ansiedlung neuer Dörfer mit der Schaffung eines Kommunikationsnetzes verbunden war, dessen lokales Zentrum die Pfarrkirche wurde.

Kościoły parafialne, zwane dawniej farnymi oprócz funkcji religijnych miały też duży wpływ na kształtowanie się lokalnej sieci komunikacyjnej. W średniowie$\mathrm{czu}, \mathrm{w}$ początkowej fazie powstawania placu targowego były one ważnym centrum społeczno-religijnym. Wokół nich koncentrował się także ruch targowy w miastach. Ponadto były one wykorzystywane przez władze jako miejsca publiczne do ogłaszania w nich swoich zarządzen' ${ }^{1}$.

Pierwsze kościoły na obszarze plemienia Warmów zostały wymienione w tekście Ugody dzierzgońskiej z 1249 r.: Warmowie zobowiązali się wówczas odbudować do Zielonych Świąt kościoly, które zostały zniszczone podczas I powstania. Miały one być okazałe i bardziej ozdobione, podkreślając wyższość nad pogańskimi świątyniami w lasach. Kościoły miały być odbudowane w następujących miejscowościach: „Jedun”, „Surimes”, „Bandadis”, „Slinia”, „Wuntenowe”, „Brusebergue”. Obszar plemiennej

\footnotetext{
1 R. Simiński, Od „solitudo” do „terra culta”. Przestrzeń jako przedmiot wyobrażeń w Inflantach i Prusach od XIII do początku XV wieku, Toruń 2008, s. 215.

2 Codex diplomaticus Warmiensis oder Regesten und Urkunden zur Geschichte Ermlands (dalej: CDW), hrsg. v. C.P. Woelky u. J.M. Saage, Bd. 1, Mainz 1860, nr 19.
} 
Warmii znacząco różnił się od dominium warmińskiego. W świetle dokumentów źródłowych Warmia plemienna sięgała znacznie dalej na północ, obejmując swoim zasięgiem zamki w Bałdze ${ }^{3}$ i w Lemptenburgu ${ }^{4}$. Duży problem w historiografii stanowi identyfikacja miejsc, w których Prusowie zobowiązali się odbudować kościoły. Pewne zamieszanie wprowadza także sam dokument Ugody dzierzgońskiej, ale opublikowany w Codex Pomeraniae, w którym zamiast Surimes i Slinia występują Butian i Niua ${ }^{5}$. Kwestia różnicy w zapisie miejscowości nie była dotąd badana. W tej sytuacji dobrze byłoby dotrzeć do oryginalnego dokumentu, aby rozwiać wszelkie wątpliwości odnośnie do wymienionych kościołów. W literaturze przedmiotu dosyć obszernie była analizowana identyfikacja wymienionych w Ugodzie kościołów ${ }^{6}$. Uważam jednak, że niektóre propozycje historyków są błędne, gdyż opierają się one jedynie na podobieństwie do nazw współcześnie brzmiących. Drugi problem stanowią sugestie naukowców dotyczące miejsc, które wykraczają poza teren plemiennej Warmii i są lokalizowane na obszarze Natangii, Sambii czy Pogezanii ${ }^{7}$. W żadnym przypadku nie została podjęta próba analizy okolicy wzmiankowanych kościołów we wczesnym średniowieczu na podstawie badań archeologicznych. Zdaniem wydawców Codex diplomaticus Warmiensis oder Regesten und Urkunden zur Geschichte Ermlands (CDW), w przypadku identyfikacji kościoła w Jedun padają propozycje oparte na podobieństwie w nazwach miejscowości, takich jak: Jadden (Gady), Gedauthen (Gieduty) czy Gedilgen (Giedyle, koło Płośnicy) ${ }^{8}$. Uważam, że bardziej wiarygodna jest teza Josefa Bendera, który lokalizuje ten kościół w Gedilgen koło Świętej Siekierki. Zwraca on uwagę, że w pobliżu tej wsi, nad rzeczką Jarft, znajdował się święty las i wzgórze, na którym znajdował się kamień ofiarny poświęcony bóstwu Kurcho9. Propozycję tę poparł także Reinhard Wenskus, który odnotował, że wieś ta została lokowana w 1262 r. pod nazwą Gedun. Niedaleko znajdowało się także grodzisko zwane Lateinerberg (Łacińska Góra). Według planu

3 Petrus de Dusburgk, Chronica Terrae Prussiae, Kraków 2007, s. 63: ad litus terrae Warmiensis.

4 CDW, Bd. 1, nr 12: in Warmia mansos duo milia et quingentos a Lemptenburc contra Lipzam mensurandos in litore in una parte et in altera contra Natangiam.

5 Codex Pomeraniae vicinarumque terrarum diplomaticus, von J.C.C. Derlichs, Berlin 1768, nr 191. W dokumencie wymienione są następujące kościoły, które Prusowie mieli odbudować na obszarze Warmii: Jeditn, Butianam, Bandadis, Niuia, Windenowe, Brunsberga.

6 J. Bender, Wiederaufnahme der in frühern Jahrgängen dieser Zeitschrift angefangenen topographischen Studien, Zeitschrift für die Geschichte und Altertumskunde Ermlands (dalej: ZGAE), Bd. 5, s. 536-580; M. Biskup, Uwagi o problemie osadnictwa i sieci parafialnej $w$ Prusach Krzyżackich $w$ wiekach XIV-XV, Komunikaty Mazursko-Warmińskie (dalej: KMW), 1983, nr 2-3 (160-161), s. 208; R. Wenskus, Prussenkirchen des Vertrages von Christburg, w: Ausgewählte Aufsätze zum frühen und preussischen Mittelalter, Sigmaringen 1986, s. 375-390; A. Radzimiński, Chrystianizacja i ewangelizacja Prusów, Toruń 2011, s. 86; M. Józefczyk, Kościół i społeczeństwo w Prusach krzyżackich. Teksty źródłowe do dziejów chrześcijaństwa w Pomezanii i Pogezanii, Elbląg 2017, s. 99-100.

J. Bender, op. cit.; R. Wenskus, op. cit., s. 357-390.

8 CDW, Bd. 1, nr 19, przyp. 15.

9 J. Bender, op. cit., s. 536-580; Preußisches Urkundenbuch (dalej: PU), Bd. I/1, hrsg. v. R. Philippi, C.P. Woelky, Königsberg 1882, nr 218, przyp. 3. 
z 1664 r., na który powołuje się Wenskus, nazywało się ono Kirchberg (Kościelna Góra $)^{10}$. Moim zdaniem drugi z wymienionych kościołów - Surimes - można identyfikować z pruskim polem Suriti, Surynis na obszarze terra Wewa ${ }^{11}$. Na podstawie powyższych zapisów kościół ten można utożsamiać z wsią Kiersiny (niem. Kirschienen), położonej na północny zachód od Pieniężna ${ }^{12}$. Uważam, że kościoła w Bandadis także należałoby szukać na obszarze ziemi Wewa. Nie jest wykluczone, że mogłaby to być wieś Bundotane, którą na podstawie dokumentu z 1292 r. możemy lokalizować na południe od Tolkowca - Tulne ${ }^{13}$. Kolejny - czwarty - kościół Prusowie mieli wybudować na Warmii w miejscowości Slinia. Identyfikacja tej nazwy budzi pewne trudności, gdyż na obszarze plemiennej Warmii źródła nie odnotowują takiej miejscowości. Możemy jedynie doszukiwać się pewnego podobieństwa z campus Salmia, czyli dzisiejszą Szalmią ${ }^{14}$. W tym przypadku należy zwrócić uwagę na fakt, że okolice Szalmii w XIII w. były zamieszkane przez Prusów. W pobliskim Gronkowie znajdowało się także monumentalne grodzisko, które według badań archeologicznych było użytkowane we wczesnym średniowieczu ${ }^{15}$. W źródłach pisanych po raz pierwszy pojawia się ono w 1289 r., jako monte Grunnenberg ${ }^{16}$. Piąty kościół miał zostać odbudowany $\mathrm{w}$ Wuntenowe. $\mathrm{W}$ tym przypadku w literaturze przedmiotu panuje powszechna zgodność dotycząca lokalizacji. Wskazuje się na Huntenau - komornictwo, które było położone w pobliżu założonego w 1266 r. zamku Brandenburg ${ }^{17}$. Ostatni - szósty kościół Warmowie mieli odbudować w Brusebergue. Także i w tym przypadku istnieją pewne rozbieżności. Wydawcy CDW są zdania, że było to Braniewo, co także moim zdaniem jest bardzo prawdopodobne. Jednak w literaturze niemieckiej panuje dosyć powszechne przekonanie, że jest to Preußisch-Bergue (Pruska Góra) koło Bergau, w parafii Lichtenhagen ${ }^{18}$. Moje wątpliwości budzi

10 R. Wenskus, op. cit., s. 385.

11 CDW, Bd. 1, nr 64 i 90 - possede et Suriti (1284), Dirsune et Surynis in terra Wewa (1292).

12 Uważam, że dotychczas historycy błędnie identyfikowali kościół w Surimes wskazując na Kłódkę lub Praslity, obie miejscowości koło Dobrego Miasta (CDW, Bd 1, nr 19, przyp. 16), czy Żugienie koło Melzaka (R. Wenskus, op. cit., s. 386-387).

13 CDW, Bd. 1, nr 90. Podobną hipotezę podali wydawcy CDW, Bd 1, nr 19, przyp. 17, jednak omyłkowo wskazali, że Bundotane było położone koło Lemitów, zamiast Demitów (patrz: campus Demyta - 1301, CDW, Bd. 1, nr 111). Propozycję Bendera i Wenskusa, że jest to kościół w Banditten i Bantlauken koło Zinten uważam za błędną, gdyż po pierwsze były to okolice należące do Natangii, a po drugie nie mamy potwierdzenia w dokumentach, aby były one opanowane przez Krzyżaków przed 1249 r., zob. - J. Bender, op. cit., s. 548-549; R. Wenskus, op. cit., s. 388.

14 Por. CDW, Bd. 1, nr 19, przyp. 18; za całkowicie błędne uważam inne propozycje, jak villa Sclunien koło Królewca, por. J. Bender, op. cit., s. 551-552; PU, Bd. I/1, nr 218, przyp. 6; R. Wenskus, op. cit., s. 386.

15 M. Jagodziński, Archeologiczne ślady osadnictwa między Wisłą a Pasłęką we wczesnym średniowieczu. Katalog stanowisk, Warszawa 1997, s. 30.

16 CDW, Bd. 1, nr 80; R. Klimek, Zaginione zamki i strażnice poświadczone w źródłach z I połowy XIV wieku na Warmii biskupiej oraz propozycje ustalenia ich lokalizacji, w: Grodziska Warmii i Mazur 1. Stan wiedzy i perspektywy badawcze, red. Z. Kobyliński, Warszawa-Zielona Góra 2013, s. 206.

17 Das Grosses Zinsbuch, hrsg. von P.G. Thielen, Marburg 1958, nr 22; CDW, Bd. 1, nr 19, przyp. 19.

18 J. Bender, op. cit., s. 552, PU Bd. 1/1, nr 218, przyp. 8; R. Wenskus, op. cit., s. 385. 
fakt, że miejscowość ta jest położona w połowie drogi między Brandenburgiem i Królewcem. W związku z tym jest mało prawdopodobne, że obszar ten należał do Warmów w XIII w. W tej sytuacji kościół w Brusebergue powinno się łączyć z Braniewem, które jest wzmiankowane w 1251 r. jako Brunesberch ${ }^{19}$.

Odbudowane przez Prusów kościoły zapewne zostały ponownie zniszczone podczas II powstania w latach 1260-1274. Po jego zdławieniu na obszarze ówczesnego dominium warmińskiego rozpoczęła się akcja kolonizacyjna, a wraz z nią budowa kościołów i sieci parafialnej. Pierwszy kościół został wybudowany w Braniewie w 1280 r. Następnie we Fromborku w 1288 r. wybudowano kościół katedralny ${ }^{20}$. Do końca XIII w. na Warmii wzniesiono dalszych siedem kościołów parafialnych: Ełdyty (1289), Szalmia (1289), Bażyny (1289), Chruściel (1296), Rogiedle (1297), Wierzno (1297) i Tolkowiec (1300). Prawdopodobnie w tym czasie powstał też kościół w Praslitach, położonych w pobliżu Rogiedli. Nazwa tej wsi lokowanej w 1361 r. brzmiała Alde Kirchen ${ }^{21}$, co znaczy dosłownie - Stary Kościół. Według tradycji w przeszłości miał się tam znajdować kościół, który został zniszczony, a miejsca jego położenia nie można już było ustalićc ${ }^{2}$. Prawdopodobnie uległ on zniszczeniu podczas któregoś z litewskich najazdów. Nie jest wykluczone, że miało to miejsce w 1300 r., kiedy Litwini najechali ziemię Glotowską i spalili jedną wieś $^{23}$. Kościoły na Warmii często powstawały w pobliżu dawnego kultu pogańskiego. Wśród takich przykładów można wymienić: Ełdyty (1289), Lidzbark Warmiński (1305), Świątki (1347), Pluty (1326), Gietrzwałd (1352) i Dywity (1366) ${ }^{24}$. Najwyraźniej chrześcijaństwo, niszcząc w pierwszej akcji symbole pogańskie, w dłuższej perspektywie korzystało jednak z lokalnej tradycji sakralnej, przypisywanej świętym miejscom pogaństwa. W ten oto sposób zawłaszczało utrwaloną wśród miejscowej ludności moc. Znajdowało to wyraz przede wszystkim we wznoszeniu w tych miejscach kościołów, które przejmowały część zakorzenionej tu tradycji dawnych kultów ${ }^{25}$. Początkowo na Warmii kościoły budowano także w centrach pruskich włości, takich jak: territorium Glotouie, district Glottouie (Głotowo 1313), terra Berting (1348), district Tlokowe (1318) czy district Plekebart (1319). Wraz z rozwojem osadniczym powstawało coraz więcej kościołów parafialnych. Największy ich rozwój miał miejsce w połowie XIV w. Do 1350 r. wzniesiono na Warmii blisko 50 kościołów. Największy rozwój sieci parafialnej miał miejsce

\footnotetext{
CDW, Bd 1, nr 27; Petrus de Dusburgk, Chronica Terre Prussiae, nr 140: Brunsbergk.

CDW, Bd. 1, nr 56 i nr 78.

21 CDW, Bd. 2, nr 318.

22 Scriptores rerum Warmiensium oder Quellenschriften zur Geschichte Ermlands (dalej: SRW), Bd. 1, hrsg. v. J.M. Saage, C.P. Woelky, Braunsberg 1866, s. 393.

${ }_{23}$ Petrus de Dusburgk, Chronica Terre Prussiae, nr 275.

24 R. Klimek, Miejsca kultu Prusów na Warmii biskupiej, KMW 2015, nr 3, s. 365-386.

25 P. Urbańczyk, Władza i polityka we wczesnym średniowieczu, Wrocław 2008, s. 181.
} 
w latach 1351-1360, kiedy założono 15 nowych parafii. Na początku XV w. Warmia, poza obszarami leśnymi w południowej części komornictwa olsztyńskiego, była szczelnie pokryta gęstą siecią parafialną. Czasy wojen, które nawiedziły obszar dominium warmińskiego w latach 1410, 1414 i 1454-1466 nie oszczędziły także kościołów ${ }^{26}$. Niektóre ze zniszczonych podczas wojennej zawieruchy świątyń z czasem odbudowano. Niektórych kościołów już nie odbudowano. W taki sposób w XV w. bezpowrotnie zniszczono kościoły parafialne: w Różynce i Wielochowie. Nie jest wykluczone, że także w Lamkowie, chociaż nie ma na to potwierdzenia w źródłach. Część spalonych budowli sakralnych została jednak z czasem odbudowana, np.: w Krekolach, Prositach, Biedkowie czy Jędrychowie ${ }^{27}$. Na podstawie dokumentu pochodzącego z końca XV w., który przedstawiał spis wszystkich kościołów i parafii w biskupstwie warmińskim, można ustalić, że w tym czasie na terenie dominium warmińskiego funkcjonowały 84 kościoły, w tym 79 parafialnych i 5 filialnych ${ }^{28}$. Wraz ze wzrostem liczby kościołów biskupstwo warmińskie dokonało podziału na mniejsze okręgi zwane archiprezbiteratami. Nie znamy dokładnej daty ich utworzenia. Po raz pierwszy wymienia je biskup Henryk III w $1341 \mathrm{r}^{29}$ Pod koniec XV w. istniało 14 takich urzędów. Na obszarze dominium warmińskiego siedziby archiprezbiteriatów mieściły się w następujących miastach: Braniewo, Frombork, Orneta, Pieniężno, Lidzbark Warmiński, Dobre Miasto, Jeziorany, Reszel i Biskupiec ${ }^{30}$. Obok kościołów parafialnych na Warmii budowano także klasztory, które służyły głównie celom misyjnym. Najwcześniej, bo jeszcze przed 1310 r. ufundowany został klasztor franciszkanów w Braniewie. W kolejnych latach powstały klasztory augustianów eremitów w Reszlu (1347) i franciszkanów w Barczewie (1364) ${ }^{31}$.

Rozwój sieci parafialnej na Warmii niósł za sobą także konieczność budowania nowych lokalnych dróg komunikacyjnych. O przebiegu trasy średniowiecznych dróg decydowały na ogół warunki terenowe. Biernie dostosowywano się do terenu, który drogi przecinały, z ominięciem większych i trudniejszych do pokonaniu przeszkód. Szlaki komunikacyjne były powiązane z powstawaniem nowych ośrodków, w których koncentrowało się życie gospodarcze czy polityczne (religijne). Trasy nowych dróg średniowiecznych cechuje znaczna liczba łuków, zakrętów, gdyż nikt nie zastanawiał się nad jej właściwym zaprojektowaniem i trasowaniem. Były one też zazwyczaj wąskie. Zdarzały się jednak odcinki, które na skutek rozjeżdżenia

26 A. Radzimiński, op. cit., s. 23-24.

27 Por. A. Olczyk, Sieć parafialna biskupstwa warmińskiego do roku 1525, Lublin 1961, s. 65-90; A. Kopiczko, Ustrój i organizacja diecezji warmińskiej w latach 1525-1772, Olsztyn 1993, s. 167-169.

28 SRW, Bd. 1, s. 400-444.

29 A. Kopiczko, op. cit., s. 163.

30 SRW, Bd. 1, s. 400-449.

31 A. Kopiczko, op. cit., s. 240. 
zajmowały powierzchnię znacznie przekraczającą pas potrzebny do ruchu. Takie rozjeżdżone miejsca powstawały zwykle w okolicach podmokłych lub na odcinkach uszkodzonych, kiedy dla ominięcia przeszkody zjeżdżano na bok. Wówczas droga stopniowo się rozszerzając przechodziła w szeroki trakt, tworząc kilka równoległych pasów. Zdarzało się to bardzo często, ponieważ prymitywne i nie umocnione drogi gruntowe nie miały ani właściwego odwodnienia, ani odpowiedniego podłoża ${ }^{32}$.

Panuje ścisły związek i zależność między rozwojem osadnictwa i rozwojem sieci drogowej. Nie sposób tego rozdzielić, gdyż wzajemnie się uzupełniają. Powiązanie drogowej sieci tranzytowej z lokalną występuje na każdym kroku. Obie niejednokrotnie przeplatają się ze sobą i nie można oddzielić badań szczegółowych nad siecią lokalną od studiów nad drogami tranzytowymi ${ }^{33}$. Drogi do kościoła najczęściej stanowiły utarte już szlaki. Jednak należy zwrócić uwagę na fakt, że zakładanie nowych parafii i lokacje nowych wsi łączyło się z powstawaniem sieci komunikacyjnej, której lokalnym ośrodkiem stawał się kościół parafialny. Naturalną przeszkodą na drogach do kościołów bywały lasy. Ich omijanie nieraz znacznie wydłużało niezbędny do pokonania dystans. Sytuacja bywała lepsza tam, gdzie zalesione przestrzenie były poprzecinane drogami. Innymi przeszkodami naturalnymi były bagna i moczary. Drogi prowadzące do kościołów omijały te przeszkody, często kosztem zwiększania koniecznych do przebycia odległości. Naturalnie dotyczyło to małych obszarów podmokłych, gdyż pasma wielkich bagien stanowiły zazwyczaj granice parafii ${ }^{34}$. Drogi parafialne niewątpliwie omijały tereny podmokłe, bagna i gęste zarośla. Stwarzały one ludności wiejskiej korzystne warunki systematycznego kontaktu z kościołem. W Polsce trasy komunikacyjne prowadzące do kościoła parafialnego nazywano „mesznymi drogami” rzadziej „mesznymi ścieżkami” ${ }^{35}$. Na obszarze średniowiecznej Warmii zazwyczaj nazywano je z języka niemieckiego Kirch wegk - czyli kościelnymi drogami ${ }^{36}$. Takie określenie dróg kościelnych sakralizowało przestrzeń leżącą poza osiedlami, jak gdyby włączając ją do kręgu kultu religijnego. Drogi prowadzące do kościołów miały w większości charakter lokalny, przy czym akceptowany powszechnie obyczaj czynił je poniekąd drogami użytku publicznego. Wydaje się, że „meszne drogi”, mimo ich szczególnego prestiżu, nie miały uprzywilejowania równego gościńcom. Dokonany na

32 A. Rosset, Drogi i mosty w średniowieczu i w czasach odrodzenia, Warszawa 1974, s. 26-28.

33 T. Dunin-Wąsowicz, Drogami średniowiecznej Polski. Studia z dziejów osadnictwa i kultury, Warszawa 2011, s. 57.

34 S. Bylina, Drogi - granice - most. Studia o przestrzeni publicznej i sakralnej w średniowieczu, Warszawa 2012, s. 19.

35 Informacja o „drodze mesznej” - ad dictam ecclesiam meszne - pojawia się m.in. w 1493 r., w nadaniu dla kościoła w Goniądzu wsi Krzeczkowo, Kodeks dyplomatyczny Katedry i Diecezji Wileńskiej, t. 1, wyd. J. Fijałek, W. Semkowicz, Kraków 1948, nr 400.

36 Porównaj mapa - Abriß der Wege zwischen Borchentsdorf, Lauck, Scepothen und Kageneu, 1586, Geheimes Staatsarchiv Preußischer Kulturbesitz, Berlin-Dahlem (dalej: GStA PK), XX HA, sygn. E 10.441: der alte Landt und Kirch wegk von Kagenaw nach der Laücke oraz der alte Kirch wegk nach Laücke. 
niej rozbój lub inne przestępstwo było karane podobnie jak wykroczenia dokonane na innych drogach lokalnych, a więc kara była łagodniejsza niż ta, która groziła za występne czyny popełnione na gościńcach ${ }^{37}$. W warmińskiej toponimii często spotykamy się z określeniami wobec tego typu traktów komunikacyjnych, jak: „kościelna droga”, czy „kościelna stecka” ${ }^{38}$. Między innymi tak nazywano: pewną drogę polną w Ramsowie, drogę polną między Purdą i Patrykami, a także między Wrzesiną i Giedajtami ${ }^{39}$. Przyjmuje się, że krzyże i figury religijne ustawiane przy takich drogach łagodziły lub rozpraszały ludzkie lęki związane z miejscami o złej sławie, które kojarzyły się z mocami obcymi chrześcijaństwu, a bliższymi wierzeniom tradycyjnym. Wedle zasługujących na uwagę przesłanek do miejsc takich zaliczały się rozdroża ${ }^{40}$. Wydaje się, że droga z Reszla do Świętej Lipki przez Ramty już w średniowieczu mogła być usłana licznymi przydrożnymi krzyżami, gdyż prawdopodobnie przechodziła przez pogański gaj Ramboten ${ }^{41}$. Na pochodzącej z 1705 r. mapie Samuela Suchodolca zaznaczono przy tej trasie liczne krzyże i opisano ją jako: Straße mit 100 figure $(n)^{42}$. Dawne drogi prowadzące do miejsca kultu miały duże znaczenie i posiadały argument broniący je przed zniszczeniem, zamknięciem i zawłaszczeniem.

Konserwacja „dróg kościelnych” pozostawała w gestii ich głównych użytkowników. Drogi te powstawały niedługo po zbudowaniu kościoła i erygowaniu parafii. Wiernych obowiązywało uczęszczanie na msze niedzielne i świąteczne we własnej parafii. Udawanie się w tym celu do innych kościołów, gdy nie było ku temu ważnej przyczyny było traktowane jako przewinienie niezdyscyplinowanych wiernych. Upominano także plebanów dopuszczających do obecności w swoim kościele obcych parafian. W porównaniu z długością innych dróg wiodących do kościołów parafialnych długość tych, które nazywane były „mesznymi”, bywała niewielka. $\mathrm{Na}$ podstawie dokumentów z obszaru Polski można ustalić długość tego typu dróg. Zazwyczaj mierzyły one od 2 do 3,5 km w linii prostej, choć w rzeczywistości bywały nieco dłuższe ${ }^{43}$. Na Warmii drogi kościelne przeważnie nie przekraczały $5 \mathrm{~km}$. Bywały jednak wsie, które były jeszcze bardzie oddalone od kościoła parafialnego.

37 Iura Prutenorum, opr. J. Matuszewski, Toruń 1963, s. 26, 36, 40 i 46; S. Bylina, op. cit., s. 26-27.

38 Wyraz „stecka”, „stegno” oznaczał w przeszłości ścieżkę udeptaną przez zwierzęta, które czasem były wykorzystywane przez ludzi wyłącznie do komunikacji pieszej, patrz: S.B. Linde, Słownik języka polskiego, t. 5: R-T, Warszawa 1995, s. 232; Z. Gloger, Encyklopedia staropolska, t. 4: P-Ż, Warszawa 1972, s. 277-278.

39 M. Pospiszylowa, Toponimia południowej Warmii. Nazwy terenowe, Olsztyn 1990, s. 53 i 84.

40 S. Bylina, op. cit., s. 40.

${ }^{41}$ CDW, Bd. 3, Leipzig 1874, nr 229; nazwy typu Rombotha oznaczały święte drzewa, które były w szczególny sposób zrośnięte, zob. - M. Praetorius, Deliciae Prussicae, oder Preussische Schaubühne, Bd. 3, Vilnius 2006, s. 108-110; C. Hartknoch, Alt- und neues Preussen, oder preussischer Historien zwei Theile, Frankfurt-Leipzig 1684, s. 291 oraz R. Klimek, Od pogańskiego miejsca kultu do chrześcijańskiego sanktuarium - Święta Lipka i Gietrzwałd na tle krajobrazu sakralnego Warmii, KMW 2016, nr 3, s. 435.

42 S. Suchodoletz, Grenze Amt Rastenburg, 1705, GStA PK, sygn. 262/D 10.033.

43 S. Bylina, op. cit., s. 28-33. 
Mieszkańcy Różańca i Nowej Pasłęki mieli 8,5 km do Braniewa, gdzie mieścił się ich kościół. Droga ta prowadziła przez podmokłe tereny przylegające do Zalewu Wiślanego i Pasłęki, więc szczególnie w okresie wiosennym była ona dla parafian uciążliwa. Wśród wsi parafialnych, których dzieliła duża odległość od kościoła parafialnego wymienić można: Ząbie (11 km do Butryn), Kabikiejmy Górne (10 km do Głotowa), Odryty (9,5 km do Barczewa), Szynowo (9 km do Barczewa), Bornity (9 km do Pieniężna), Kiersztanowo (8,5 km do Ramsowa), Kudypy (8,2 km do Olsztyna), Wróblik (7,5 km do Kraszewa), Kaszuny (7 km do Ornety). Niektóre wsie przynależały do kościołów parafialnych, chociaż nierzadko do innych miały bliżej. Takim przykładem jest wieś Kabikiejmy Górne, której mieszkańcy musieli uczęszczać do kościoła w Głotowie, mimo tego, że do Sętalu mieli tylko 2,5 km. Także parafianie ze Świętnika nadkładali drogi do Lidzbarka Warmińskiego $(6,5 \mathrm{~km})$, chociaż do Kłębowa mieli tylko 2,5 km. W przypadku kilku wsi wydawać się może, że zimą drogi do kościoła parafialnego prowadziły przez zamarznięte jezioro, zaś latem z wykorzystaniem łodzi (dłubanki). Mieszkańcy Kręska mieli do kościoła w Sząbruku drogą lądową $9 \mathrm{~km}$, ale z wykorzystaniem drogi wodnej, przez jezioro Wulpińskie, odległość ta zmniejszała się do 3,5 km. Długa podróż na niedzielną mszę kościelną czekała także niektórych mieszkańców parafii w Gryźlinach. I tak mieszkańcy wsi Pluski musieli przebyć drogą lądową 10 km, zaś ludność z Kucharzewa $14 \mathrm{~km}$. Także w tym przypadku nie wykluczam wykorzystania drogi przez jezioro Pluszne, co adekwatnie skracało ją do $6 \mathrm{~km}$ z Plusek i $10 \mathrm{~km} \mathrm{z} \mathrm{Kucharzewa.}$

W średniowieczu na Warmii doszło także do powstania ruchu pątniczego. Głównym miejscem pielgrzymek było Głotowo ${ }^{44}$ i Bisztynek. Gdy w Głotowie oddawano szczególną cześć Najświętszemu Ciału Pana Jezusa, to w Bisztynku czczono Przenajdroższą Krew. Według informacji zawartej w kronice z lat 1526-1537, kiedy biskup Sorbom w 1400 r. konsekrował kościół w Bisztynku i odprawiał Mszę świętą przy ołtarzu Świętego Krzyża, podczas Podniesienia ukazały się krople krwi spływające $z$ hostii na ołtarz. Fakt ten odbił się głośno na Warmii i zapoczątkował ruch pątniczy ${ }^{45}$. Ponadlokalny charakter pielgrzymkowy miała Święta Lipka leżąca przy granicy dominium warmińskiego. Źródłowe świadectwo o pielgrzymce mamy już z 1473 r. Wówczas kapłan Maciej ze Śluzowa ubolewał, że wierni z diecezji płockiej pielgrzymują tam, chociaż miejsce to nie było wówczas obdarzone żadnymi odpustami ${ }^{46}$. Kronikarz Lukas David pisał o tym, że będąc małym chłopakiem, uczestniczył ze swoją matką w pielgrzymce do Świętej Lipki. Lukas David opisał, jak pątnicy kładli na wagę mięso w ofierze - w konkretnych intencjach. Przytoczył przykład małego chorowitego chłopaka, którego posadzono na jednym krańcu

${ }_{44}$ J. Leo, Dzieje Prus, Olsztyn 2008, s. 166-167.

45 A. Kopiczko, op. cit., s. 192-193.

46 J. Hochleitner, Przydrożne pomniki kultu religijnego Świętej Lipki i okolic, Studia Angerburgica, t. 11, 2006, s. 78. 
szali wagi, zaś na drugi kładziono w ofierze mięso, do momentu aż jego waga przekroczyła wagę chłopca. W ten sposób wierzono, że ofiara spełniona w Świętej Lipce uleczy chorowitego chłopaka ${ }^{47}$. Drogi pielgrzymek zasadniczo pokrywały się z drogami handlowymi. Na pewnych odcinkach jednak się od nich oddalały. Pielgrzymi na ogół wybierali drogi na przełaj, bezdroża, omijając wielkie szlaki komunikacyjne. Wiązało się to $\mathrm{z}$ możliwością znalezienia taniego, albo bezpłatnego noclegu, a także obozowania ${ }^{48}$.

„Drogi kościelne” na Warmii miały dla jej mieszkańców duże znaczenie. Świadczyć o tym mogą liczne kapliczki, które zdobią krajobraz kulturowy tej krainy. Chociaż dziś mijane przydrożne kapliczki pochodzą najczęściej z XIX w lub z początku XX w., to jednak zazwyczaj powstawały one na fundamentach starszych, które nadszarpnięte zębem czasu ulegały powolnemu zniszczeniu ${ }^{49}$. Nie jest wykluczone, że obyczaj stawiania przydrożnych kapliczek oraz krzyży był kultywowany na Warmii od czasów średniowiecza.

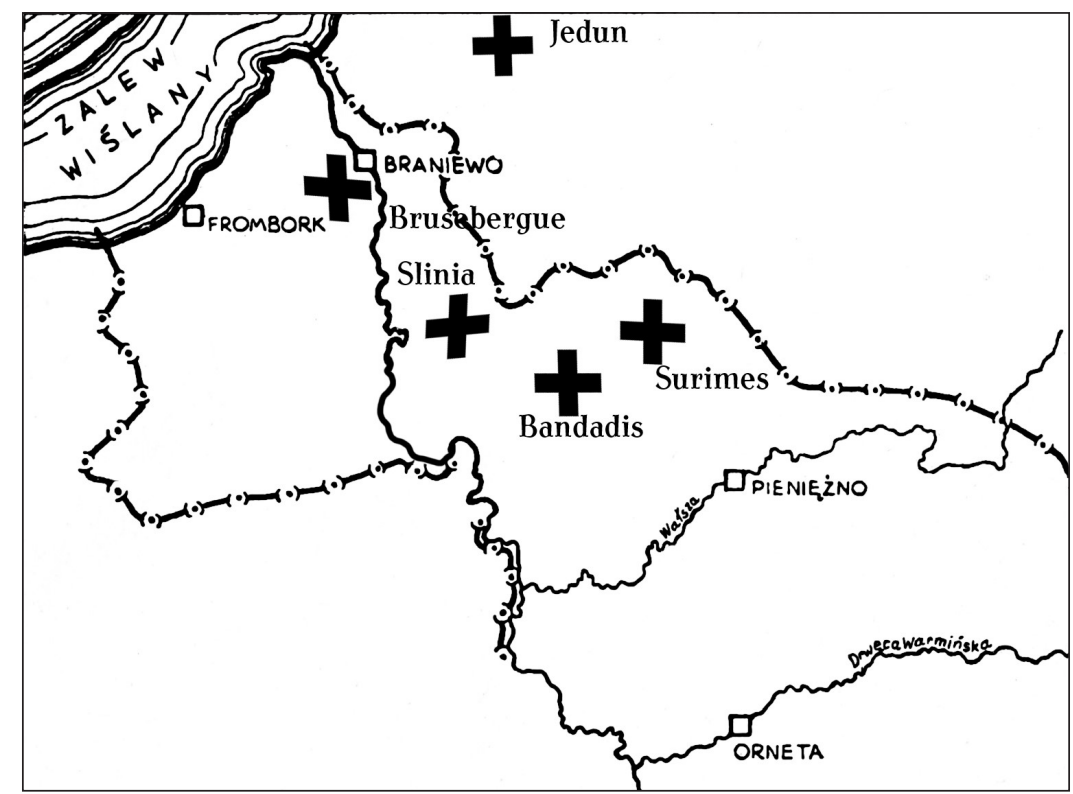

Domniemana lokalizacja kościołów na obszarze Warmii plemiennej w 1249 r., oprac. R. Klimek

47 L. David, Preussische Chronik, hrsg. E. Hennig, Bd. 1, Königsberg 1812, s. 151-152.

48 T. Dunin-Wąsowicz, Drogami średniowiecznej Polski, s. 387-388.

49 Podczas analizy rękopiśmiennych map Schroettera (F. Schroetter, Tableau zur Zusammensetzung Karte von Preussen, Section 39, 1796, skala 1:50000, Deutsche Staatsbibliothek, sygn. N 1020) zauważyłem, że naniesione są na niej kapliczki przydrożne i krzyże, które wzniesiono w XIX w. lub na początku XX w. W tej sytuacji mamy do czynienia z kontynuacją odnawiania obiektów kultu religijnego. 


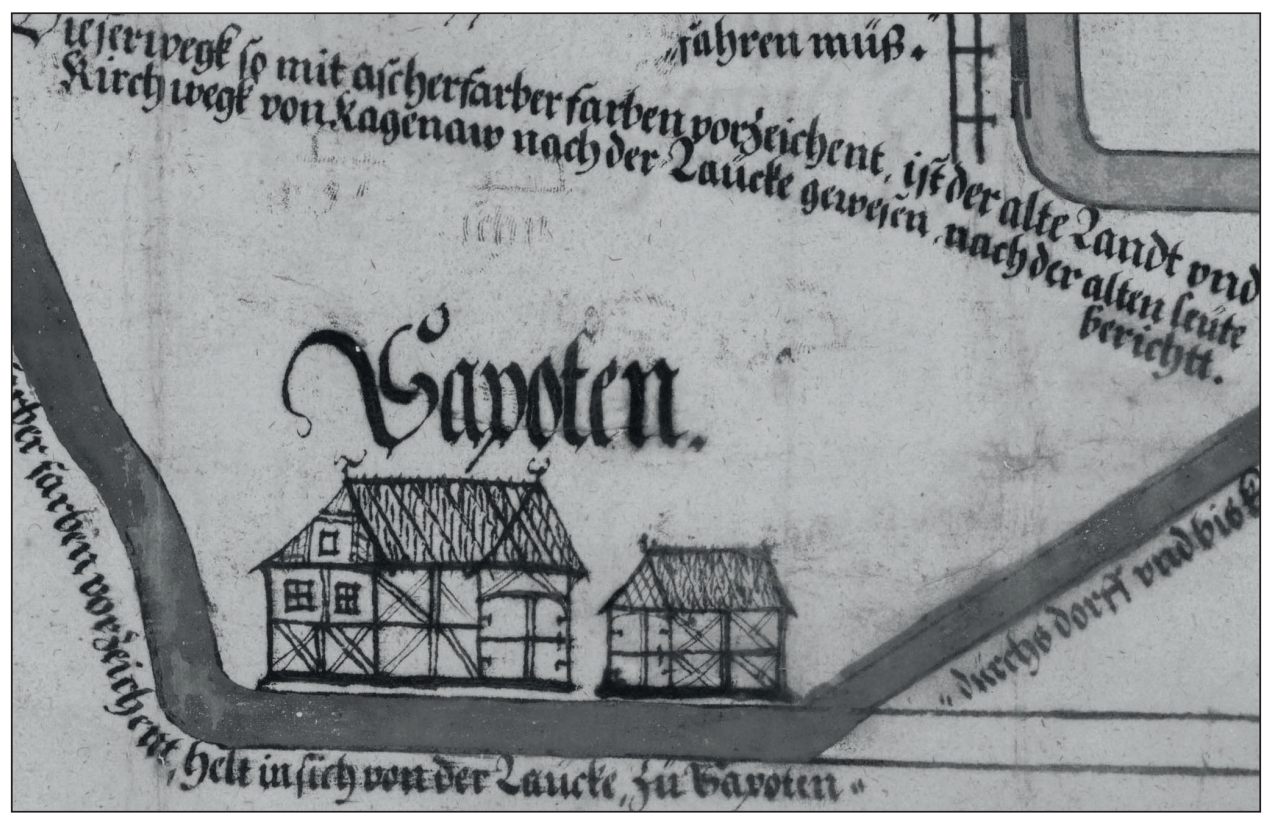

Fragment mapy z 1586 r. z opisem drogi kościelnej - Kirch Wegk, GStA PK, sygn. E 10.441

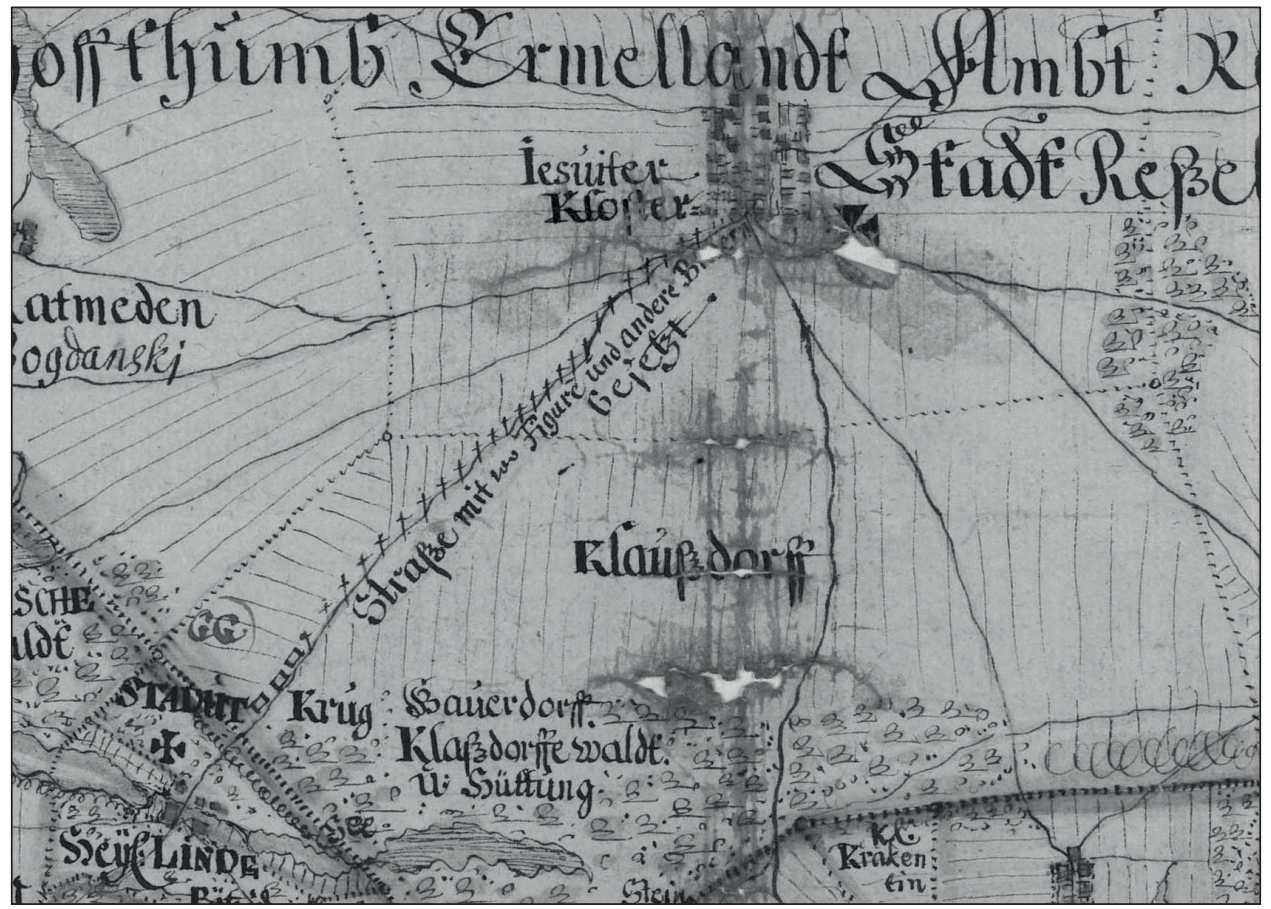

Fragment mapy Samuela Suchodolca z 1705 r. z opisem drogi z Reszla do Świętej Lipki Straße mit 100 figure(n), GStA PK, sygn. D 10.033 


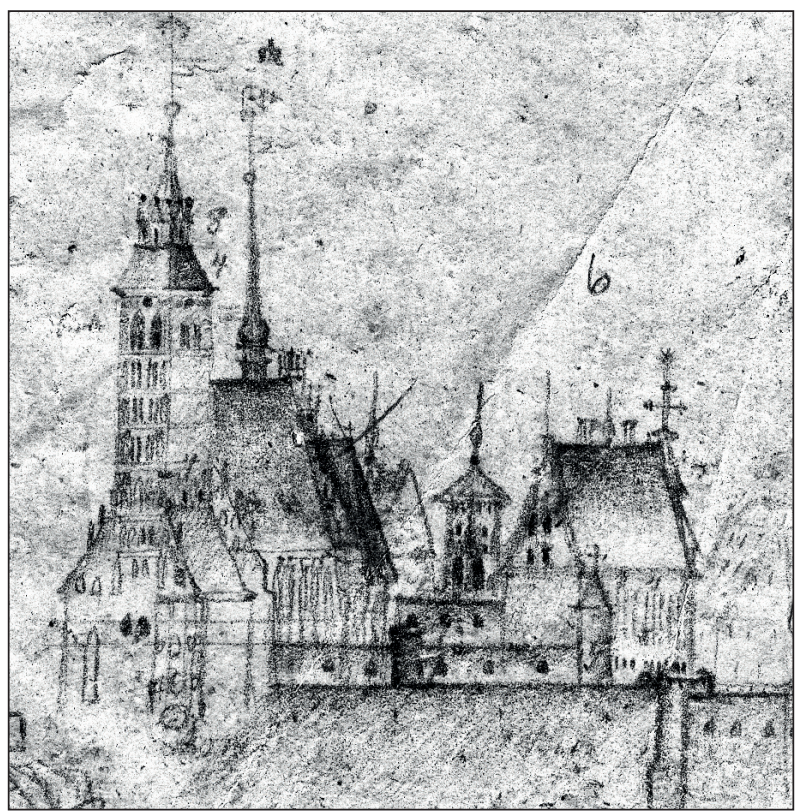

Katedra w Braniewie wg. archiwalnego szkicu Johanna Guise z 1826 r., SMB PKMVF, Guise Zettel, sygn. PMIXh 00178B

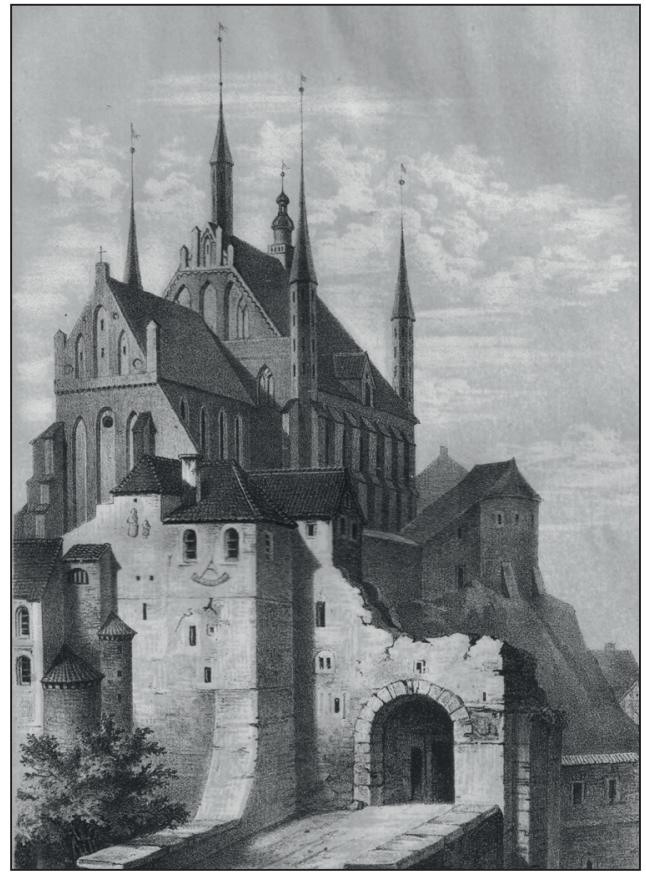

Katedra we Fromborku, litografia (1838) ze zbiorów autora 


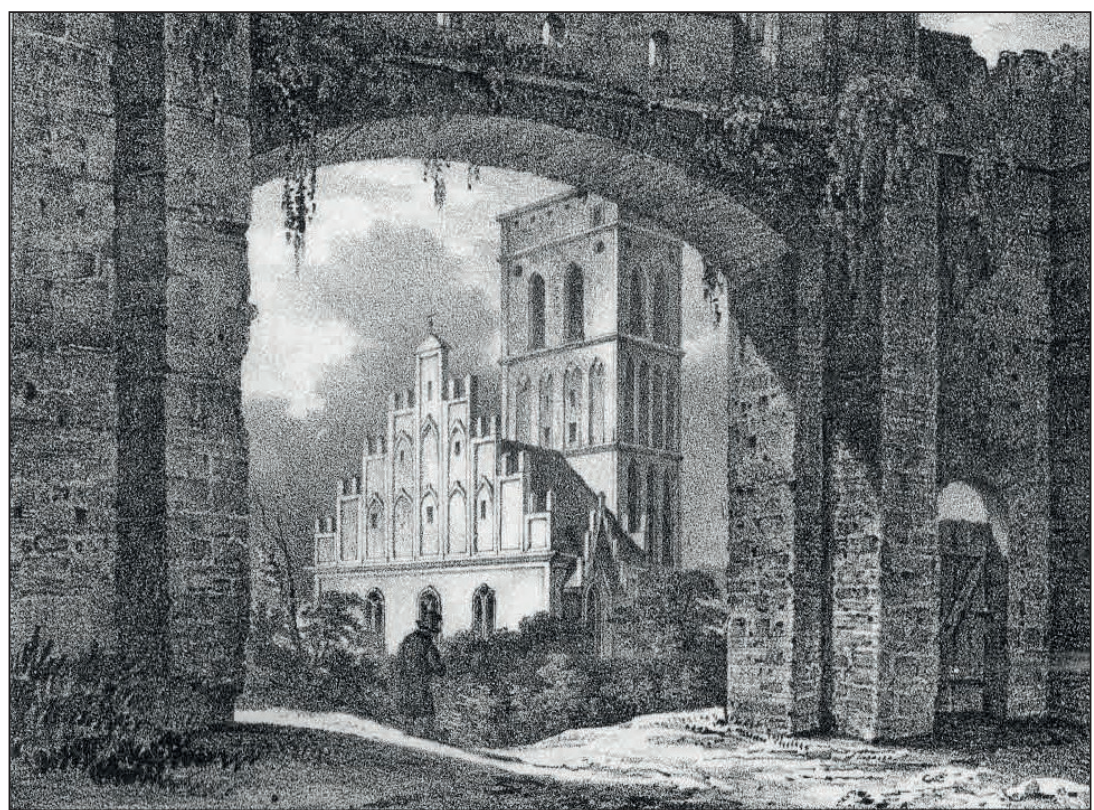

Kościół parafialny w Reszlu, litografia (1838) ze zbiorów autora

\section{BIBLIOGRAFIA}

\section{Archiwalia}

Abriß der Wege zwischen Borchentsdorf, Lauck, Scepothen und Kageneu, 1586, Geheimes Staatsarchiv Preußischer Kulturbesitz, Berlin-Dahlem, XX HA, sygn. E 10.441: der alte Landt und Kirch wegk von Kagenaw nach der Laücke oraz der alte Kirch wegk nach Laücke.

Schroetter Friedrich, Tableau zur Zusammensetzung Karte von Preussen, Section 39, 1796, skala 1:50 000, Deutsche Staatsbibliothek, sygn. N 1020.

Suchodoletz Samuel, Grenze Amt Rastenburg, 1705, GStA PK, sygn. 262/D 10.033.

\section{Źródła drukowane}

Codex diplomaticus Warmiensis oder Regesten und Urkunden zur Geschichte Ermlands, hrsg. v. C.P. Woelky u. J.M. Saage, Mainz 1860:

- $\quad$ Bd. 1, nr 19, 27, nr 56, 64, 78, 80, 90, 111.

- $\quad$ Bd. 2, nr 318.

- $\quad$ Bd. 3, nr 229.

Codex Pomeraniae vicinarumque terrarum diplomaticus, von J.C.C. Derlichs, Berlin 1768, nr 191.

Das Grosses Zinsbuch, hrsg. von P.G. Thielen, Marburg 1958, nr 22.

David Lucas, Preussische Chronik, hrsg. E. Hennig, Bd. 1, Königsberg 1812.

Dusburgk Petrus de, Chronica Terre Prussiae, Kraków 2007, nr 18: ad litus terrae Warmiensis.

Iura Prutenorum, opr. J. Matuszewski, Toruń 1963.

Kodeks dyplomatyczny Katedry i Diecezji Wileńskiej, t. 1, wyd. J. Fijałek, W. Semkowicz, Kraków 1948, nr 400.

Preußisches Urkundenbuch, Bd I/1, hrsg. v. R. Philippi, C.P. Woelky, Königsberg 1882, nr 218.

Scriptores rerum Warmiensium oder Quellenschriften zur Geschichte Ermlands, Bd 1, hrsg. v. J. M. Saage, C.P. Woelky, Braunsberg 1866. 


\section{Opracowania}

Bender Joseph, Wiederaufnahme der in frühern Jahrgängen dieser Zeitschrift angefangenen topographischen Studien, Zeitschrift für die Geschichte und Altertumskunde Ermlands, Bd. 5.

Biskup Marian, Uwagi o problemie osadnictwa i sieci parafialnej w Prusach Krzyżackich w wiekach XIV-XV, Komunikaty Mazursko-Warmińskie, 1983, nr 2-3 (160-161).

Bylina Stanisław, Drogi - granice - most. Studia o przestrzeni publicznej i sakralnej w średniowieczu, Warszawa 2012.

Dunin-Wąsowicz Teresa, Drogami średniowiecznej Polski. Studia z dziejów osadnictwa i kultury, Warszawa 2011.

Gloger Zygmunt, Encyklopedia staropolska, t. 4: P-Ż, Warszawa 1972.

Hartknoch Christoph, Alt- und neues Preussen, oder preussischer Historien zwei Theile, Frankfurt-Leipzig 1684.

Hochleitner Janusz, Przydrożne pomniki kultu religijnego Świętej Lipki i okolic, Studia Angerburgica, t. 11, 2006.

Iura Prutenorum, opr. J. Matuszewski, Toruń 1963.

Jagodziński Marek, Archeologiczne ślady osadnictwa między Wisłą a Pasłęką we wczesnym średniowieczu. Katalog stanowisk, Warszawa 1997.

Józefczyk Mieczysław, Kościół i społeczeństwo w Prusach krzyżackich. Teksty źródłowe do dziejów chrześcijaństwa w Pomezanii i Pogezanii, Elbląg 2017.

Klimek Robert, Zaginione zamki i strażnice poświadczone w źródłach z I połowy XIV wieku na Warmii biskupiej oraz propozycje ustalenia ich lokalizacji, w: Grodziska Warmii i Mazur 1. Stan wiedzy i perspektywy badawcze, red. Z. Kobyliński, Warszawa-Zielona Góra 2013.

- $\quad$ Miejsca kultu Prusów na Warmii biskupiej, Komunikaty Mazursko-Warmińskie, 2015, nr 3.

- Od pogańskiego miejsca kultu do chrześcijańskiego sanktuarium - Święta Lipka i Gietrzwałd na tle krajobrazu sakralnego Warmii, Komunikaty Mazursko-Warmińskie, 2016, nr 3.

Kopiczko Andrzej, Ustrój i organizacja diecezji warmińskiej w latach 1525-1772, Olsztyn 1993.

Leo Jan, Dzieje Prus, Olsztyn 2008.

Linde Samuel Bogumił, Słownik języka polskiego, t. 5: R-T, Warszawa 1995.

Olczyk Aniela, Sieć parafialna biskupstwa warmińskiego do roku 1525, Lublin 1961.

Pospiszylowa Anna, Toponimia południowej Warmii. Nazwy terenowe, Olsztyn 1990.

Praetorius Mätthaus, Deliciae Prussicae, oder Preussische Schaubühne, Bd. 3, Vilnius 2006.

Radzimiński Andrzej, Chrystianizacja i ewangelizacja Prusów, Toruń 2011.

Rosset Adriana, Drogi i mosty w średniowieczu i w czasach odrodzenia, Warszawa 1974.

Simiński Rafał, Od „solitudo” do „terra culta”. Przestrzeń jako przedmiot wyobrażeń w Inflantach i Prusach od XIII do początku XV wieku, Toruń 2008.

Urbańczyk Przemysław, Władza i polityka we wczesnym średniowieczu, Wrocław 2008.

Wenskus Reinhard, Prussenkirchen des Vertrages von Christburg, w: Ausgewählte Aufsätze zum frühen und preussischen Mittelalter, Sigmaringen 1986. 